\title{
The Haitian Educational Problematic
}

\section{Mocombe PC*}

West Virginia State University, The Mocombeian Foundation, USA

*Corresponding author: Paul C Mocombe, West Virginia State University, The Mocombeian Foundation, 316 Hill Hall, Institute, WV 25112, USA, Email:

\section{Research article}

Volume 2 Issue 1

Received Date: August 06, 2019

Published Date: October 18, 2019

DOI: $10.23880 /$ abca-16000107 pmocombe@mocombeian.com

\section{Abstract}

In this work, using a structurationist approach, phenomenological structuralism, to understanding the constitution of society and practical consciousness, I argue that Haiti's educational model is a colonial one, an ideological apparatus established by a French-speaking minority, the mulatto elites and petit-bourgeois blacks, i.e., Affranchis, in order so that they can participate in the global capitalist world-system as descendants of their former colonial administrators while the African majority are interpellated and subjectified as laborers for sports and the entertainment industries, tourism, and export agriculture and manufacturing jobs provided by America, France, and Canada. Thus, in Haiti the attempt for a long time has been on following the black American bourgeois model of integration into the capitalist world-system by integrating the masses into the social class language game of their former colonial slavemasters (the French) at the expense of constituting their own social class language based on the Kreyol language and Vodou metaphysics of the majority of the African inhabitants of the country.

Keywords: Vodou Ethic; Spirit of Communism, Structurationism; Vodou; Dialectical; Anti-dialectical; Affranchis; Bois Caiman; Boukman Dutty; Phenomenological Structuralism; Haitian Epistemology; Haitian/Vilokan Idealism

Abbreviations: HBCU: Historically Black Colleges and Universities; MIT: Massachusetts Institute of Technology.

\section{Introduction}

Like the Africans of North America who were enslaved by the British, the Africans of Haiti were enslaved by the French on plantations to reproduce the colonial mercantilist system of global capitalism. Unlike the black American, which became a structurally differentiated black other in America. In Haiti, given that sixty-seven percent of the population where directly from Africa when the Revolution commenced, following the Haitian Revolution, many of the Africans were able to maintain and institutionalize their practical consciousness in the mountains and provinces of the island via the Kreyol language, the lakou system, and the Vodou Ethic and the spirit of communism [1-3]. Hence two opposing forms of system and social integration (i.e., social class language games), each with their own mode of production, language, ideology, ideological apparatuses, and communicative discourse, would constitute the Haitian social structure [1,3]. The Vodou Ethic and the spirit of communism of the Africans; and the Protestant Ethic and the spirit of capitalism of the Affranchis, mulatto elites 
and petit-bourgeois blacks [1]. The latter, given their interpellation and embourgeoisement in European languages, mode of production, ideology, ideological apparatuses, and communicative discourse, sought to continue their participation in the global capitalist processes of the Europeans. The former sought to constitute an alternative form of system and social integration, i.e., a libertarian communal social class language game, by which they sought to interpellate and socialize the masses for subsistence living and sustainable development of the material resource framework over capitalist exploitation. Haiti's educational problematic, which is due to "a mismatch of linguistic structure and social class function," rests on the fact that two opposing educational models developed in the country, each tied to the aforementioned forms of system and social integration. The elites established a system for themselves based on the French educational model with its emphasis on literature, the arts and humanities, and foreign languages with French as the language of instruction. This model was established at the expense of the African majority who were and are left uneducated in the latter system so as to fulfill their structural roles as tourist, agricultural, and factory laborers within the society for global capital. Conversely, the Africans established a system based on oral traditions, herbal medicine, and the ideology of Vodou with instruction in the Kreyol language. Lack of resources and the ideological apparatuses (i.e., laws, economic policies, etc.) and communicative discourse of the former system have undermined the development of the latter in favor of the former, which has led to the social, economic, and educational problematics of the people and the nationstate.

For me, in building on the theory of learning and development highlighted in Paul C. Mocombe's [4] structurationist theory of phenomenological structuralism, Haiti's educational system, given that as a homogeneous speech community, i.e., social class language game, dominated by Africans and the Kreyol language, should be tied to the development and codification of the grammar of the Kreyol language, the peoples' mode of subsistence agriculture, physics, psychology in particular and medicine in general, and socio-history with Kreyol as the language of instruction so as to constitute the society for subsistence living and the sustainable reproduction of the material resource framework. The latter processes constitute the fundamental basis of the lakou system and the Vodou Ethic and the spirit of communism. As it stands, however, Haiti's educational model is a colonial one, an ideological apparatus established by a French-speaking minority, the mulatto elites and petit-bourgeois blacks, i.e., Affranchis, in order so that they can participate in the global capitalist world-system as descendants of their former colonial administrators while the African majority are interpellated and subjectified as laborers for sports and the entertainment industries, tourism, and export agriculture and manufacturing jobs provided by America, France, and Canada. Thus, in Haiti the attempt for a long time has been on following the black American bourgeois model of integration into the capitalist world-system by integrating into the social class language game of their former colonial slavemasters (the French) as agricultural and technical workers at the expense of constituting their own social class language based on the Kreyol language and Vodou metaphysics of the majority of the African inhabitants of the country.

\section{Background of the Problem}

Traditional interpretations of the Haitian Revolution, and subsequent to that the constitution of Haitian identity, attempt to understand them, like the constitution of black diasporic and American practical consciousnesses, within the dialectical logic of Hegel's master/slave dialectic $[2,3,5,6]$. Concluding that the Haitian Revolution represents a struggle by the enslaved Africans of the island who internalized the liberal norms, values, and rules of their former French masters, for equality of opportunity, recognition, and distribution within and using the metaphysical discourse of their former white slavemasters to convict them of not identifying with their norms, rules, and values as recursively (re) organized and reproduced by blacks. Haitian identity/practical consciousness, as such, was and is a simulacrum, of European practical consciousness and identity, which is universalized and presented as the nature of reality as such. This position, predominantly held by white Westerners, is usually juxtaposed against the postmodern, post-structural, and postcolonial approaches of Haitian and other black bourgeois intellectual elites (i.e., Aime Cesaire), which highlight the hybridity, ambivalence, negritude, syncretism, indigenisme, and creolite, of the Revolution and Haitian consciousness.

Both interpretations, contrary to the position of Haitian intellectuals such as Jacques Roumain and JeanPrice Mars, who advised the Haitian intelligentsia class to look to the provinces and the peasant classes to constitute Haitian culture, identity, and nation-state, are problematic in that they are ethnocentric and racist. They both 
overlook the initial African practical consciousness of the majority of the Africans on the island for either the practical consciousness or discourse and discursive practices of the mulatto, Arab, and petit-bourgeois black elites, Affranchis, looking (because of their interpellation and embourgeoisement) to Europe, Canada, and America for equality of opportunity, recognition, and distribution, or for their (Affranchis) logic of postmodern, poststructural, and postcolonial theories to undermine that African presence in favor of notions of hybridity, creolite, negritude, syncretism, intersectionality, double consciousness, etc.

In their assumption of control of the state and its ideological apparatuses, i.e., schools, churches, police force, laws, military, etc., in other words, the Affranchis, as the whites before them, attempted to repress, "silence," through anti-superstitious laws to outlaw Vodou and economic policies to undermine its mode of production, the Vodou Ethic and the spirit of communism social class language game of the Africans for their own Eurocentered purposive-rationality, even though, paradoxically, many of them exercised aspects of the latter in secrecy [3]. Furthermore, their dialectical, postmodern, post-structural, and post-colonial textual productions, as seen in the works of Louis-Joseph Janvier, Thomas Madiou, Beaubrun Ardouin, Herard Dumesle, and Antenor Firmin among many others, minimized and minimize the African structuring structure to highlight hybridity, creolite, negritude, ambivalence, and contradictions. In other words, they accentuate and substantiate the European practical consciousness as recursively reorganized and reproduced by whites, mulattoes, and petit-bourgeois blacks, but minimize the African in the ambivalence, creole, negritude, and hybrid language of postmodern, post-structural, and postcolonial discourses, which are still, dialectically, Western in origins and constitution.

\section{Theory and Method}

Essentially, the argument here is that there is no creole, negritude, ambivalent, hybrid, etc., consciousness by which Haitians of the nation-state reified and reify their social structure and went/go about recursively reorganizing and reproducing its ideas and ideals as their practical consciousness. My structurationist position, phenomenological structuralism, ultimately views identity and consciousness as the product of power relations within a structure, tied to the mode of production, which attempts to reduce human agency by forcing (via ideology, ideological apparatuses, communicative discourse, language, and the mode of production) actors to internalize its ideas and ideals and recursively (re) organize and reproduce them as their practical consciousness $[1,4,7]$. Hence social structure or a social class language game is a duality and dualism: reified as a structure via ideology, ideological apparatuses such as education and the family, communicative discourse, language, and mode of production whose concepts are in-turn internalized and recursively organized and reproduced as the practical consciousness of individual human actors. Be that as it may, the logic here is that Haitians, the minority Affranchis, either recursively reorganize and reproduce as an "other" the ideas and ideals of the Republican state, the Catholic/Protestant Ethic and the spirit of capitalism social class language game, as their practical consciousness or those of the Vodou Ethic and the spirit of communism of the mass majority. Postmodern, poststructural, and postcolonial discourses are the language, ideology, and communicative discourse of post-industrial Catholic/Protestant capitalist social relations of production recursively reorganized and reproduced by the Affranchis in the language of creolite, hybridity, indigenisme, negritude, double consciousness, etc., for equality of opportunity, recognition, and distribution with their former colonizers and slavemasters. That is to say, ambivalence, hybridity, liminality, creolite, negritude, double consciousness, etc., are the psychological processes, concepts, pathologies, and practical consciousness of the Affranchis bourgeoisies as they desire and struggle for equality of opportunity, recognition, and distribution with whites by reproducing their ideas and ideals as their practical consciousness in order to convict them (whites), amidst their racism and discrimination, for not identifying with their values and norms as revealed by black practices, i.e., practical consciousness. As though by highlighting their alleged ambivalence, double consciousness, negritude, and syncretism as opposed to the singular "African" otherness, reflected in the practical consciousness of the masses, which allowed for them to be discriminated against to start with, affords them, Affranchis, their desires (equality of opportunity, recognition, and distribution) and the sympathy of whites.

Essentially, when the Haitian Revolution commences in 1791, there are three distinct groups vying for control of the island, the whites (blancs); free people of color and mulattoes (Affranchis), and the enslaved and escaped (maroon) Africans of the island. The latter, over sixtyseven percent of the population, were not a structurally differentiated other. They had their own practical 
consciousness, what Paul C. Mocombe [1] calls the "Vodou Ethic and the spirit of communism," by which they went about recursively (re)organizing and reproducing the material resource framework via the lakou system (Lakouism). The former two, free blacks and gens de couleur (Affranchis), were interpellated, embourgeoised, and differentiated by the language, communicative discourse, mode of production, ideology, and ideological apparatuses of the West and shared the same European practical consciousness, the Catholic/Protestant Ethic and the spirit of capitalism social class language game, as the whites. The latter social class language game stood against the Vodou Ethic and the spirit of communism social class language game of the majority of the Africans who were interpellated and ounganified/manboified by the language, communicative discourse, mode of production, ideology, and ideological apparatuses of oungan yo, manbo yo, gangan yo, and granmoun yo [1$3,5]$.

Be that as it may, four distinct Revolutions would come to constitute the Haitian Revolution: The Revolutions of the whites; mulattoes; creole blacks and former generals; and the Africans. The whites, were divided between large plantation owners, grand blanc, and petit-blancs, i.e., managers, slave drivers, artisans, merchants, and teachers [2]. The former, grand blanc, were independent-minded, and like the American colonists wanted political and economic independence from their mother-country, France, where their rights and economic interests were not represented in the National Assembly. The petit-blancs were more racist and feared the alliance between the larger landowners and the Affranchis. The Affranchis were free people of color and mulatto, gens de couleur, property and slave owners on the island who shared the religion, culture, language, and ideology of their white counterparts and wanted then Saint-Domingue to remain a French colony. Although internal antagonism based on race (color) and class existed between the free (creole) blacks and gens de couleur, I group them together under the nomenclature, Affranchis, to highlight the fact that their interpellation and embourgeoisement via the ideological apparatuses of the West rendered their practical consciousnesses identical even though there were racial/color (based on phenotype, not ideology) tensions between them (racial tensions, which still plaques Haiti today). Unlike the majority of white large plantation owners, however, the Affranchis, like Vincent Oge, Andre Rigaud, Alexandre Petion, Pierre Pinchinat, Toussaint Louverture, for examples, did not want independence from France. In the case of the mulattoes, who after independence would come to be referred to as the children of Alexandre Petion, the first mulatto president of the Haitian Republic, they simply wanted their social, political, and economic rights recognized by France within the colony, not an independent nation-state or the end to slavery. In regards, to the children of Dessalines/Toussaint, creole slave drivers and free blacks, they sought equality of opportunity, recognition, and distribution vis-à-vis the whites and mulattoes. The enslaved and escaped Africans, the children of Sans Souci, of the island were divided between field slaves, domestic slaves, and maroons. The domestic slaves, like their African-American counterparts, "house slaves," more so identified with their slavemasters. However, for the most part, the field slaves and maroons, because of their relative isolation from whites, domestic slaves, gens de couleur, and free blacks, were interpellated and ounganified/manboified by the modes of production, language, ideology, ideological apparatuses, and communicative discourse of the Vodou Ethic and the spirit of communism, and many sought to reproduce their African ways of life in a national position of their own. In the end, the Revolution would come down to a struggle between the Affranchis and the enslaved and maroon Africans of the island, the latter of whom commenced the Haitian Revolution on August 14 ${ }^{\text {th }}, 1791$ at Bois Caiman and other congresses [1-3,5].

Following the Revolution, between 1804 and 1806, the purposive-rationality of the enslaved and maroon Africans would become a part of the modus operandi of the Haitian nation-state until October 17, 1806 when Jean-Jacques Dessalines, the founding father of the Haitian nation, was assassinated by Alexandre Petion and Henri Christophe. At which point, the purposive-rationality of the Affranchis with their emphasis on integration into the mercantilist and free-trade dialectical logic of the global capitalist world-system, capitalist wealth, French culture, religion, and language became dominant at the expense of the African linguistic system, Kreyol; Vodou ideology; its ideological apparatuses; and modes of production, subsistence agriculture, husbandry, and komes, of the African masses on the island who took to the mountains and provinces following the death of Dessalines [2,3]. This is not to say that Dessalines completely sided with the purposive-rationality or practical consciousness of the African masses who sought to recursively reproduce their Vodou Ethic and spirit of communism, i.e., subsistence agriculture, husbandry, and komes (commerce), practical consciousness on the island via the lakou system. The argument here is that via his nationalization project, he attempted to balance the purposive-rationality of his grandon class of former generals and slave drivers, i.e., 
the creole blacks, who yearned to become wealthy landowners and masters like the whites and racist mulatto elites amidst the desires of the African masses seeking to reproduce their subsistence agriculture, husbandry, and komes. Be that as it may, the internal struggles between the two bourgeoisies within the Affranchis, the mulatto elites who controlled the export/import trade and the free blacks who controlled the land and agribusinesses where the African masses toiled as cultivators, over control of the state and its ideological apparatuses would dominate the political and economic conditions of post-revolution Haiti to the present at the expense of the practical consciousness of the African masses $[2,3,5,6]$. Both groups would arm the youth and peasants of the island to achieve their initiatives, i.e., control of the state and its ideological apparatuses. Today, the latter, grandon class, composed of educated professionals, former drug dealers, entertainers, and police officers (mercantilists or protectionists) attack the former (free-trading) Affranchis class, which is now a comprador bourgeoisie seeking to build, own, and manage hotels and assembly factories producing electronics and clothing for the US market, under the moniker the children of Jean-Jacques Dessalines against the children of Alexandre Petion in the name of the African masses of the island, the majority of whom are peasant farmers (the children of Sans Souci and Macaya, i.e., Congolese leaders of the Revolution who wanted no part of the capitalist world-system) seeking to recursively (re) organize and reproduce the lakou system and the Vodou Ethic and the spirit of communism as their form of system and social integration against the Protestant Ethic and spirit of capitalism.

\section{Discussion and Conclusions}

Building on Paul C Mocombe's [1,4] theory of phenomenological structuralism, which views the constitution of society based on five elements or systems (mode of production, language, ideology, ideological apparatuses, and communicative discourse) that constitute its social class language game or social structure the concepts of which are internalized and reproduced as the practical consciousness of human actors, it is clear as outlined above that Haiti's educational problematic rests on the fact that the elites have attempted to interpellate and embourgeois the African masses to participate in the global capitalist world-system of the Europeans as laborers against the attempt to reproduce the lakouism and Vodou Ethic and the spirit of communism of the former group who are the majority. This has led to a mismatch of linguistic structure and social class function between the two forms of system and social integration.

Hence, whereas early on in the history of the nationstate the emphasis of the elites was on an educational system, for the elites who governed the country, based on the French and Catholic models heavily geared towards literature, the arts and humanities, and foreign languages with French as the language of instruction $[3,8]$. When the US occupied (1915-1934) the country they sought, based on what they did for the black Americans with the establishment of Historically Black Colleges and Universities (HBCUs) as technical, agricultural, and mechanical schools following the American Civil War, to constitute the educational system of the island around technical and mechanical training for the masses so that they can fulfill their labor roles as a periphery nationstate producing agricultural and manufacturing productions for the First World or core states. Following the occupation, the Haitian elites, for the most part, returned to their French model, in defiance of the US, at the expense of technical training and the hardcore sciences, i.e., physics, etc., with French as the language of instruction [8]. The Africans in the mountains and provinces either relied on the Catholic Church for their education, or the oral traditions, herbal knowledge, and ideologies of the lakous under Vodou priest and priestesses [9-15].

As a result of this socio-history, contemporarily, the Haitian educational system is constituted as a three-tier system. The first tier is based on the French and Catholic models directed towards the education of the elites with instruction in French. The emphasis in this tier is on literature, foreign languages, and the humanities and arts. The second tier is based on the American model of vocational and technical training with instruction also taking place in French so as to facilitate the role of the masses as technical, agricultural, and mechanical laborers for global capital. Albeit, there is a push for Kreyol instruction in the early stages of this latter tier as was the case somewhat under the American occupation. The third tier is based on Vodou, herbal medicine, and the oral traditions of the Africans with instruction solely in Kreyol under the control of Vodou priest and priestesses in the mountains and provinces of the country. This latter model is less formal than the former two under the control of the state, church, and NGOs [15-20].

In my view, in order for the Haitian educational system to truly be liberating the emphasis should be twofold: institutionalizing the grammar of the Kreyol 
language as the medium of and for instruction; and provide training in physics, psychology and medicine, and the general (physical and earth) sciences (via the grammar of Kreyol as the language of instruction) for the reproduction of the mode of production, which should be tied to the sustainability of the human being and the material resource framework of the island as highlighted in the lakou system of the Africans of the provinces and mountains. This latter work is the intent of the Haitian Initiative coming out of the Massachusetts Institute of Technology (MIT) under the direction of Michel deGraffe [20-25].

In other words, at the base of the libertarian communism of the lakou system emanating from the Vodou Ethic and the spirit of communism is agricultural production at the family level for subsistence living, trade, and independence so that the individual can live free and equal to all. Expanding the system at the national-state level would mean, 1) promoting agricultural production at the family level for subsistence living and trade; 2 ) light manufacturing, textile production, etc. on every lakou for lakou consumption; 3) tertiary industries for service and entertainment at the lakou communal level; 4) infrastructure, i.e., schools, roads, medical facilities on each lakou provided by the state as a result of taxation of each lakou, not the individual; 5) community policing provided by each lakou; military provided by the state via recruitment from the lakous.

In the aggregate, this socioeconomic lakou system would be governed politically as the Africans did prior to the advents of Islam and Christianity on the continent. Traditional West African political structures were constituted around "a hierarchical bureaucracy of kings who were regarded as being invested by divine right, ruling in accordance with the will of the ancestors and some omnipotent power [25-30]. The kings had their own councils and advisers, or ministers of state, who supervised military affairs, external affairs, the treasury, justice, courts, etc. The various subordinate districts within the kingdoms had their rulers, and the villages had their headmen". In the constitution of the contemporary Haitian nation-state via the lakou system as enframed by the Vodou Ethic and the spirit of communism, in place of the king would be the president ruling in accordance with the will of the ancestors and the people [31-36]. The president would have their own councils and advisers, or ministers of state, who supervised military affairs, external affairs, the treasury, justice, courts, etc. He/she would be appointed for life by the representative body, parliament, of the various communes and communal sections within the nation-state. This parliament would constitute a political body replaced every seven years by lot, like the American jury system, from each lakou, which would be governed by its headperson as determined by the will of the ancestors and the people of the lakous, of the communes and communal sections. In essence, the emphasis would be on constituting and reproducing society based on the physics and meta-physics of individual constitution, which connects the individual and society to nature, as highlighted in the libertarian communism of their Vodou Ethic and the spirit of communism [37-40].

Contemporarily, however, instead of vertically integrating the libertarian communism of the lakou system and the Vodou Ethic and the spirit of communism (expanding the agricultural capacities of each lakou; establishing centers of secondary industries for local consumption and exports on each lakou; facilitating the rise of tertiary industries on the lakous for leisure and entertainment; and providing schools, medical facilities, which combine holistic medicine with western, and other infrastructure) to achieve the vision of total democracy, equality, sustainable development, and liberty among the Kreyol speaking African masses to constitute the Haitian nation-state [41-45]. The black skinned, white-masked elites (Frantz Fanon's term), under the neoliberal projects of the World Bank and International Monetary Fund, seek to integrate Haiti as a periphery-state by displacing the Africans off the land in order to facilitate their migration to the capital cities of the state and other countries where the masses become a cheap labor force to be exploited for global capital and the Haitian bourgeoisie operating manufacturing and textile factories for the West [46-50]. The educational system as such becomes one of interpellating the masses as vocational workers and athletes for the sports and entertainment industries, tourism, and factories of the local and global economy. However, their inabilities-given the voting power of the majority-to constitute two dominant rotating political parties to implement the desires of their former white colonial slave masters, leaves Haiti in perpetual turmoil [51-54]. As in slavery, the African masses continue to fight, against their interpellation, embourgeoisement, and differentiation as wage-earners (commodities) in the tourism trade and textile factories of the Catholic/Protestant Ethic and spirit of capitalism of these two power elites seeking equality of opportunity, recognition, and distribution with whites at their expense. As the current historical conjuncture parallels the mercantilist/free-trade economic conjuncture of 1791 either a unifying national conference that parallels Bois 
Caiman or a second war of independence will determine the outcome of this perpetual economic and cultural civil war in Haiti [55-60]. As for now, the masses of Port-auPrince, galvanized by the grandon class, protest against the neoliberal capitalist world-system under American hegemony under the moniker, the children of Petion v. the children of Dessalines. Although viewed within racial terms, Petion representing the mulatto elites and Dessalines the African masses, the metaphor, contemporarily, have come to represent Marxist ideological categories for racial-class (nationalistic) struggles on the island of Haiti against dictatorship, the Haitian oligarchs, and American neoliberal policies on the island: the ideological position of Petion representing the neoliberal views of the mulatto elites and petit-bourgeois blacks; and Haitian nationalism, economic reform, and social justice representing the ideological position of Dessalines as articulated by educated segments of the petit-bourgeois class claiming to speak for the African masses, the majority of whom are more so the descendants of Macaya and Sans Souci (African soldiers who fought against the Affranchis when France attempted to reconquer the island in 1801) than Petion or Dessalines/Toussaint $[61,62]$.

\section{References}

1. Mocombe PC (2016) The Vodou Ethic and the Spirit of Communism: The Practical Consciousness of the African People of Haiti 22(2): 163-166.

2. Dubois L (2004) Avengers of the New World. Massachusetts: Harvard University Press, pp: 384.

3. Dubois L (2012) Haiti: The Afterschocks of History. Metropolitan Books, New York.

4. Mocombe PC (2019) The Theory of Phenomenological Structuralism. Newcastle upon Tyne, Cambridge Scholars Publishing, pp: 201.

5. James CLR (1986) The Black Jacobins: Toussaint L' Ouverture and the San Domingo Revolution. Vintage.

6. Buck-Morss Susan (2009) Hegel, Haiti, and Universal History. University of Pittsburgh Press, pp: 160.

7. Mocombe PC (2018) Mind, Body, and Consciousness in Society: Thinking Vygotsky via Chomsky. Newcastle upon Tyne, Cambridge Scholars Publishing, UK, pp: 237.
8. Robertshaw M (2018) Occupying Creole: The Crisis of Language Under the US Occupation of Haiti. The Journal of Haitian Studies 24 (1): 4-24.

9. Althusser L (2001) Lenin and Philosophy and Other Essays. Monthly Review Press, New York, pp: 272.

10. Althusser L, Etienne B (1970) Reading Capital, NLB, London.

11. Balibar E, Immanuel W (1991 [1988]) Race, Nation, Class: Ambiguous Identities. Verso, London.

12. Bourdieu P (1990) The Logic of Practice. Stanford University Press, California, pp: 340.

13. Bourdieu P (1984) Distinction: A Social Critique of the Judgement of Taste. Harvard University Press, Cambridge, pp: 1-613.

14. Chase-Dunn C, Peter G (1995) World-Systems Analysis. Annual Review of Sociology 21: 387-417.

15. Chase-Dunn C, Richard R (1977) Toward a Structural Perspective on the World-System. Politics \& Society 7(4): 453-476.

16. Chase-Dunn C (1975) The effects of international economic dependence on development and inequality: A cross-national study. American Sociological Review 40(6): 720-738.

17. Cohen J (2002) Protestantism and Capitalism: The Mechanisms of Influence. Cambridge University Press 76(4): 903-906.

18. Crothers C (2003) Technical Advances in General Sociological Theory: The Potential Contribution of Post-Structurationist Sociology. Perspectives 26(3): 3-8.

19. Dahrendorf R (1959) Class and Class Conflict in Industrial Society. Stanford University Press California, pp: 621-622.

20. Douglas M (1986) How Institutions Think. Syracuse University Press, New York, 158.

21. Drake Claire (1965) The Social and Economic Status of the Negro in the United States. American Academy of Arts \& Sciences 94(4): 771-814. 
22. Fanon (1967) Black Skin, White Masks. Grove Press, New York.

23. Fanon F (1963) The Wretched of the Earth. Grove Press, New York.

24. Michel F (1977) Discipline and Punish: The Birth of the Prison. Penguin Books, London.

25. Franklin JH, Alfred AM (2000) From Slavery to Freedom: A History of African Americans. New York.

26. Fraser N (1997) Justice Interruptus: Critical Reflections on the "Postsocialist" Condition. Routledge New York.

27. Franklin EF (1939) The Negro Family in United States. University of Chicago Press Chicago, pp: 727.

28. Franklin EF (1957) Black Bourgeoisie: The Rise of a New Middle Class. The Free Press, New York.

29. Franklin EF (1968) The Free Negro Family. Arno Press, The New York.

30. David G (2002) Bourdieu's Theory of Cultural Change: Explication, Application, Critique. Sociological Theory 20 (2): 255-277.

31. Anthony G (1984) The Constitution of Society: Outline of the Theory of Structuration. Polity Press Cambridge, pp: 402.

32. Gutman HG (1976) The Black Family in Slavery and Freedom 1750-1925. Pantheon Books, New York.

33. Jurgen $H$ (1987) The Theory of Communicative Action: Lifeworld and System: A Critique of Functionalist Reason. Beacon, Press Boston, pp: 1457.

34. Jurgen H (1984) The Theory of Communicative Action: Reason and the Rationalization of Society Beacon Press, Boston, pp: 1-236.

35. Nathan H (1991) The Black Anglo-Saxons.Third World Press. Chicago.

36. Holloway JE (1990) Africanisms in American Culture. Bloomington and Indianapolis: Indiana University Press.
37. Holloway JE (1990) The Origins of African-American Culture. In: Holloway JE $2^{\text {nd }}($ Ed.), Bloomington and Indianapolis: Indiana University Press.

38. Horkheimer M, Theodor WA (2000) Dialectic of Enlightenment. New York.

39. Kenneth H, Coukos A (2005) The Dark Side of the Protestant Ethic: A Comparative Analysis of Welfare Reform. Sociological Theory 23 (1): 1-24.

40. Maulana K (1993) Introduction to Black Studies. The University of Sankore Press, California.

41. Douglas K (2002) Theorizing Globalization. Sociological Theory 20(3): 285-305.

42. Kurtz LR (2007) Gods in the Global Village: The World's Religions in Sociological Perspective. Sage Publications, California.

43. Lincoln EC, Mamiya LH (1990) The Black Church in the African American Experience. Duke University Press, London, pp: 536.

44. Lukacs G (1971) History and Class Consciousness: Studies in Marxist Dialectics. The MIT Press, Cambridge.

45. Lukacs G (2000) A Defence of History and Class Consciousness: Tailism and the Dialectic. Verso, New York.

46. Marcuse H (1964) One-Dimensional Man. Beacon Press, Boston, pp: 320.

47. Marcuse H (1974) Eros and Civilization: A Philosophical Inquiry into Freud. Beacon Press, Boston, pp: 312.

48. Marx K, Friedrich E (1964) The Communist Manifesto. Penguin Books, England, pp: 432.

49. Marx K (1867) Capital: A Critique of Political Economy. International Publishers, New York.

50. Marx K (1998) The German Ideology. Prometheus Books, New York.

51. McMichael P (2008) Development and Social Change: A Global Perspective. Sage Publications, California. 
52. Mocombe PC, Carol T, Christine C (2017) The African Americanization of the Black Diaspora in Globalization or the Contemporary Capitalist Worldsystem. Journal of Developing Societies 31(4): 467487.

53. Ortner SB (1984) Theory in Anthropology Since the Sixties, Comparative Studies in Society and History 26(1): 126-166.

54. Orlando P (1982) Slavery and Social Death: A Comparative Study. Harvard University Press 25(4): 89-93

55. Reed AL (1997) W.E.B. Du Bois and American Political Thought: Fabianism and the Color Line. Oxford University Press, New York.

56. Kidder FE (1960) Caribbean Studies: A Symposium. In: $2^{\text {nd }}$ (Ed.), Rubin $V$ Seattle, University of Washington Press, Washington, pp: 202.
57. Ramsey K (2011) The Spirits and the Law: Vodou and Power in Haiti. University of Chicago Press, Chicago.

58. Sklair L (1995) Sociology of the Global System. Westview Press, Baltimore.

59. Smith MG (1960) The African Heritage in the Caribbean. In: Vera R (Ed.), Caribbean Studies: A Symposium. University of Washington Press.

60. Wallerstein I (1982) The Rise and Future Demise of the World Capitalist System: Concepts for Comparative Analysis. Studies in Society and History 16(4): 387-415.

61. Weber Max (1958) The Protestant Ethic and the Spirit of Capitalism. Charles Scribner's Sons, New York.

62. West C (1993) Race Matters. Vintage Book, New York. 